\title{
The Role of Cooperative in The Milk Value Chain in West Bandung Regency, West Java Province
}

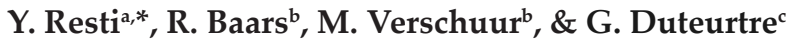 \\ aDiploma Program of Bogor Agricultural University \\ Jalan Kumbang No. 14, Bogor 16151, Indonesia \\ bVan Hall Larenstein University of Applied Sciences \\ PO Box 9001, 6880 GB Velp, the Netherlands \\ 'UMR SELMET CIRAD-INRA-SUPAGRO, Campus International de Baillarguet \\ Montpellier Cedex 5, 34398, France \\ (Received 14-08-2017; Reviewed 02-10-2017; Accepted 14-11-2017)
}

\begin{abstract}
The objective of the study was to evaluate the capacity of Northern Bandung Dairy Farmer Cooperative (KPSBU) to support farmers in producing good quality milk within the milk value chain in West Bandung Regency, West Java. The study used qualitative research strategies including desk study, case study, and focus group discussions. The study compared the involvement of three milk collecting actors that were classified into large cooperative (KPSBU), small cooperative (KUD Puspa Mekar), and private company (Bina Kitri Bersama). A total of 18 dairy farmers, 3 milk collecting actors, 2 milk processors, and one livestock officer were interviewed. Three focus group discussions were conducted. The large cooperative performed better in services, milk collection, and milk quality assessment compared to other milk collecting actors. Members' commitment, inconsistent milk quality, and shortage of good quality fodder were the hindering factors that influenced the collection of good quality milk in the large cooperative. In conclusion, the large cooperative had better performance in service provision, it also had better infrastructures in milk collection and milk quality assessment compared to other milk collecting actors. Increasing the milk quality standard by milk processing companies affected the milk price since 2000 .
\end{abstract}

Keywords: dairy farmer, cooperative, milk quality, milk value chain, value chain governance

\section{ABSTRAK}

Penelitian dilakukan untuk mengevaluasi kinerja Koperasi Peternakan Susu Bandung Utara (KPSBU) dalam mendukung peternak untuk memproduksi susu yang berkualitas baik dalam rantai tata nilai susu di Kabupaten Bandung Barat, Jawa Barat. Penelitian ini menggunakan metode kualitatif meliputi studi literatur, studi kasus, dan diskusi kelompok terfokus. Penelitian dilakukan dengan membandingkan aktivitas dari tiga aktor yang terlibat dalam proses distribusi susu yang diklasifikasikan ke dalam koperasi besar (KPSBU), koperasi kecil (KUD Puspa Mekar), dan perusahaan swasta (Bina Kitri Bersama). Wawancara dilakukan kepada 18 peternak sapi perah, 3 kolektor susu, 2 perusahaan pengolahan susu, dan Dinas Peternakan Kabupaten Bandung Barat. Disamping itu juga dilakukan 3 diskusi kelompok terfokus. Hasil penelitian menunjukkan bahwa koperasi besar memberikan pelayanan yang lebih baik terutama dalam proses pengumpulan dan penilaian kualitas susu dibandingkan dengan dua aktor lainnya. Komitmen anggota, fluktuasi kualitas susu dan kekurangan pakan berkualitas merupakan faktor penghambat yang mempengaruhi kualitas susu di koperasi besar. Meningkatnya standar kualitas susu oleh perusahaan pengolahan susu telah mempengaruhi harga susu semenjak tahun 2000. Disimpulkan bahwa koperasi besar memiliki performa yang lebih baik dalam penyediaan layanan, infrastruktur penampungan susu dan penilaian kualitas susu yang lebih baik dibandingkan dengan kolektor susu yang lain.

Kata kunci: peternak sapi perah, koperasi, kualitas susu, rantai nilai susu, value chain governance

*Corresponding author:

E-mail: iyhest@gmail.com 


\section{INTRODUCTION}

Demand for milk and milk products in Indonesia is rising fastly, due to population growth, increasing purchasing power and new consumers' preferences for dairy products. In 2013, the total population of dairy cows has reached 622,000 heads producing 1,018 thousand tonnes milk per year, which represents a $23 \%$ increasement in milk quantities since 2009 (DJPKH, 2013). Local fresh milk supplied $22 \%$ of the total milk supply in the country, the rest being provided by imports of various products and raw materials (Priyanti \& Soedjana, 2015).

Milk is mainly produced by smallholder dairy farmers, organized in a large number of cooperatives. Over $90 \%$ of the fresh milk is collected through village cooperatives (KUD) and supplied to milk processing industries. The rest is collected through private collectors. Java island contributed for nearly $99 \%$ of the total milk production. About 100 dairy cooperatives operate in Java as a whole, involving almost 100,000 dairy farmers members, and delivering the milk to more than 30 milk processing companies. Most of those cooperatives are members of the Indonesian Union of Dairy Cooperatives (GKSI) (Morey, 2011). Dairy cooperatives have a crucial and active role in the milk value chain in encouraging the dairy industry as most of the small scale dairy farmers are organized through cooperatives. Value chain is coordinated value-adding activities that link producers to the end consumers. The firms add values in a coordinated way from the raw materials to the final products adding value at each level in a profitable and sustainable ways (FAO, 2014). However, dairy farming system and the whole dairy chain face many technical and institutional limitations. The farmers are not able to get premium price, while the cooperatives are not able to get quality and reliable supply of milk from the farmers. As the milk quality is directly linked to the low milk price the farmers and the cooperatives get, it led to the dependency of farmers and cooperatives on the processors. Furthermore, the farmers and the cooperatives always depend on the processors for their milk price. The farmers and the cooperatives have no influence on decision making of the milk price. As such, evaluating the capacity of KPSBU as a large cooperatives that supports farmers to produce good quality milk is a priority research question. Answering to it can help to identify key technical or institutional innovations to develop the dairy business in this region.

\section{METHODS}

The study was carried out in West Bandung Regency, West Java Province. The West Java province is the second province in terms of milk output: it produces $1 / 3$ of the national production. The province hosts totally around 23 cooperatives, including in particular the Southern Bandung Dairy Farmer Cooperative (KPBS) based in Pangalengan, and the Northern Bandung Dairy Farmer Cooperative (KPSBU) based in Lembang. Those are the 2 largest cooperatives in terms of milk collection in the Province. West Bandung Regency had more than 7000 dairy farmers in 2015. Most dairy farmers were members of KPSBU, and the remaining ones sold their milk either to some other cooperatives or to private collectors.

\section{Data Collection}

There were 2 types of milk collecting actors involved in West Bandung District, the dairy cooperatives and private milk collecting companies. In this study, the milk collecting actors were classified into large cooperative (KPSBU), small cooperative (KUD Puspa Mekar) and private collectors (Bina Kitri Bersama/BKB) (Table $1)$. In each class, six farmers were individually interviewed. Three focus group discussion were conducted, with six farmers each. The farmers who had been interviewed individually were not involved in focus group discussion. The milk collecting actors identified which individuals and groups of dairy farmers to choose for the interviews. The milk collecting actors explained that it was based on the access and location of the dairy farmers, the ability of the farmers to speak in Bahasa and the time availability of the farmers. In addition, six experts were interviewed. In order to understand the activities done by different stakeholders in the milk value chain, keen observation was required.

\section{Data Analysis}

The stakeholder matrix and value chain map were used to analyze general information of the milk value chain. Comparison matrix of milk collecting actors was used to analyze the findings of organisational, economic and members level. The organisation level concentrates on how the organisation works and link with the stakeholders in the milk value chain. The economic level helps to explore the role of the stakeholders and how the cooperative performs in the business environment. The members' level assisted to explain and compared the existing variations in services delivery, milk collection and milk quality assessment among the members.

Table 1. Respondent category and numbers

\begin{tabular}{lc}
\hline \multicolumn{1}{c}{ Category of respondent } & $\begin{array}{c}\text { Numbers of } \\
\text { respondents }\end{array}$ \\
\hline Producers affiliated to large cooperative & 6 \\
Producers affiliated to small cooperative & 6 \\
Producers selling to private collectors & 6 \\
Large cooperative (staff) & 1 \\
Small cooperative (staff) & 1 \\
Private collector (staff) & 1 \\
Government livestock services (staff) & 1 \\
Milk processing companies (staff) & 2 \\
Total & 24 \\
\hline
\end{tabular}




\section{RESULTS}

The stakeholder analysis and milk value chain map are shown in Table 2 and Figure 1.

\section{Chain Governance of Milk Collecting Actors}

Value chain governance is the correlation among stakeholders to control the product requirement within the chain, which includes activities to regulate and implement the parameters. The study defined governance into the dimensions activities, membership, coordination and regulations (Table 3 ).

\section{Milk Collection and Milk Quality}

The members of the dairy cooperatives were divided into several cooperative service places (CSP). This division was based on the region of the farmers. Farmers in CSP were further subdivided into several temporary milk group for determining milk prices. CSP was the first collection point to trace the source of milk. Each CSP had its own milk collection point (Table 4).

\section{Milk Payment and Milk Price}

All the milk collecting actors followed the same payment process every month. The price of milk was de-

Table 2. Stakeholders involvement in milk value chain in West Bandung Regency

\begin{tabular}{|c|c|c|}
\hline No. & Stakeholders & Activities \\
\hline A & Actors & \\
\hline \multirow[t]{6}{*}{1} & Input suppliers: & \\
\hline & $\begin{array}{l}\text { Artificial insemination centre - Lembang (BIB } \\
\text { Lembang) }\end{array}$ & Provide frozen semen. \\
\hline & Animal feed companies, KUD & Sell cattle concentrate. \\
\hline & Agro vet companies & Sell veterinary medicine. \\
\hline & Farm equipment companies & Sell farm equipment. \\
\hline & Cattle Breeders & Sell dairy cattle replacement stocks. \\
\hline 2 & $\begin{array}{l}\text { Milk producers } \\
\text { Small holder dairy farmers: Mostly family farms }\end{array}$ & $\begin{array}{l}\text { As dairy farmers, the producers have to make sure that their } \\
\text { farms are able to supply milk daily to the milk collectors. }\end{array}$ \\
\hline \multirow[t]{3}{*}{3} & Milk collectors: & \\
\hline & $\begin{array}{l}\text { Dairy cooperatives (KPSBU, KUD Puspa Mekar, } \\
\text { KUD Sarwa Mukti) }\end{array}$ & $\begin{array}{l}\text { Milk collection, link farmers to the processors and small scale } \\
\text { processing, provide services to their members. }\end{array}$ \\
\hline & $\begin{array}{l}\text { Private milk collecting companies (Bina Kitri } \\
\text { Bersama, PT Agro Mandiri, CV Barokah, Lambada } \\
\text { and Tugu Mandiri) }\end{array}$ & $\begin{array}{l}\text { Collect milk from non-cooperatives farmers, sell milk to process- } \\
\text { ing plants, and provide services to their members. }\end{array}$ \\
\hline 4 & $\begin{array}{l}\text { Small-scale and large milk processors (PT Insan } \\
\text { Muda Berdikari, Serba Susu, PT Alfa, PT Indolakto, } \\
\text { PT Frisian Flag Indonesia, PT Diamond Cold } \\
\text { Storage, PT Yummy Food Utama, PT Nutrifood, PT } \\
\text { Cisarua Mountain Dairy) }\end{array}$ & $\begin{array}{l}\text { Process milk into UHT milk, pasteurized milk, cheese, ice cream, } \\
\text { yoghurt and sell their products to the customers and consumers. }\end{array}$ \\
\hline 5 & $\begin{array}{l}\text { Retailers } \\
\text { Hotel, supermarkets }\end{array}$ & Sell fresh milk and processed milk to the end consumers \\
\hline 6 & Consumers & $\begin{array}{l}\text { Purchase the products from supermarkets or directly from milk } \\
\text { collectors' supermarkets and consume them with or without } \\
\text { processing. }\end{array}$ \\
\hline B & Supporters and Influencers & \\
\hline 1 & $\begin{array}{l}\text { NGO's, international / national organisations (Biru, } \\
\text { Sahabat Cipta Foundation) }\end{array}$ & $\begin{array}{l}\text { Technical and financial support in the milk value chain, capacity } \\
\text { building of farmers and extensions }\end{array}$ \\
\hline \multirow[t]{7}{*}{2} & Governments: & \\
\hline & Ministry of Cooperatives & Authorization of cooperative establishment \\
\hline & Ministry of Forestry & Provide land for forage to limited cooperative members \\
\hline & Ministry of Agriculture & $\begin{array}{l}\text { Provide technical and non-technical services to few members and } \\
\text { policy formulation to all of the actors. }\end{array}$ \\
\hline & $\begin{array}{l}\text { Financial institutions (Ministry of Finance, Bank } \\
\text { BRI, Bank BCA, Bank Jabar) }\end{array}$ & $\begin{array}{l}\text { Provide subsidy for credit interest to selected cooperative mem- } \\
\text { bers, loan and saving accounts to some members. }\end{array}$ \\
\hline & Indonesian Dairy Cooperatives Union (GKSI) & $\begin{array}{l}\text { Organizing farmers' cooperative and negotiate selling prices on } \\
\text { behalf of their primary cooperatives and provide services such as } \\
\text { training, financial audits and other business services }\end{array}$ \\
\hline & $\begin{array}{l}\text { Universities (Padjajaran University, Bogor } \\
\text { Agricultural University) }\end{array}$ & $\begin{array}{l}\text { Doing consultancy on dairy development, conduct research and } \\
\text { capacity building }\end{array}$ \\
\hline
\end{tabular}




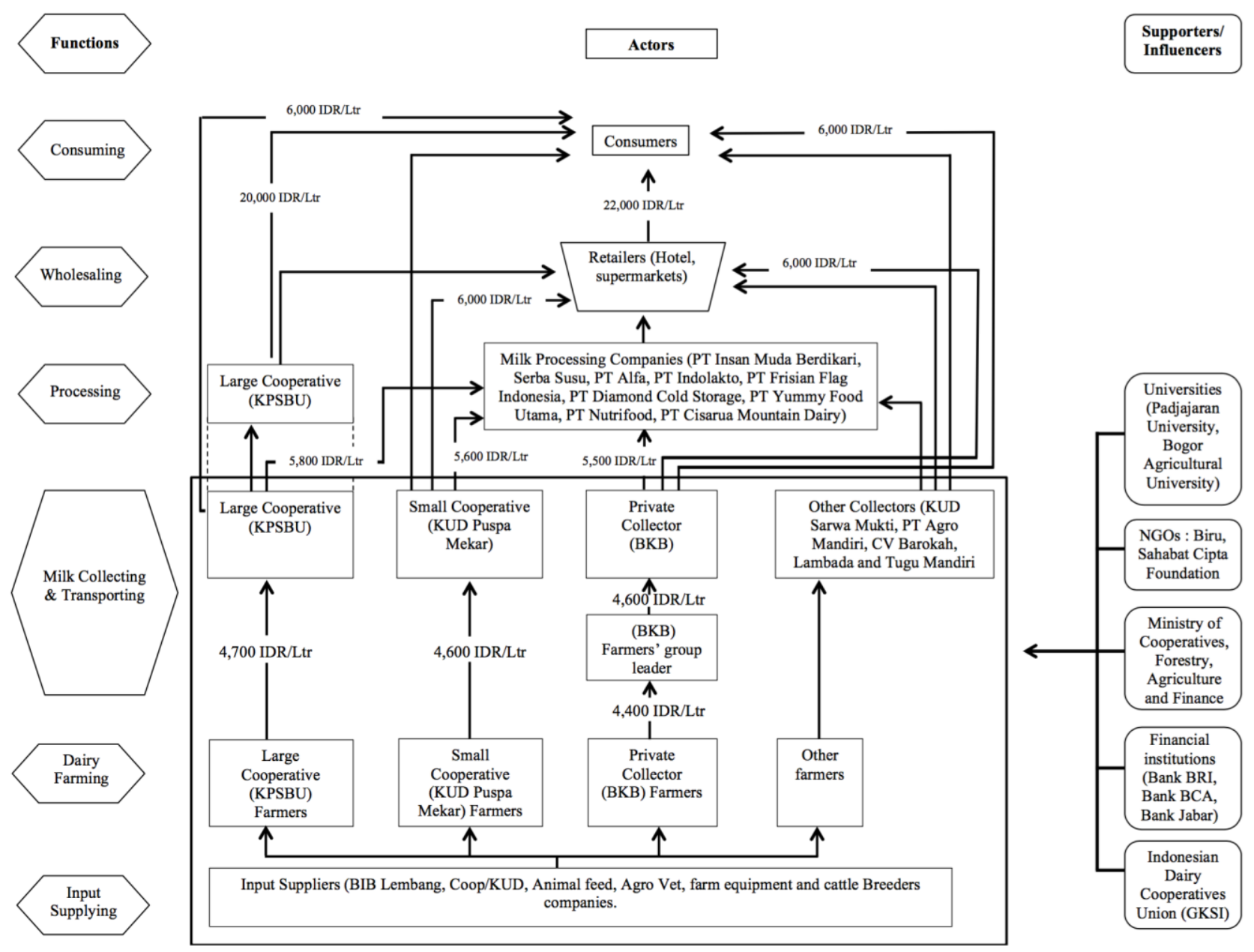

Figure 1. The milk chain map in West Bandung Regency

Table 3. The governance of milk collecting actors in West Bandung Regency

\begin{tabular}{llll}
\hline Parameters & Large cooperative & Small cooperative & Private collectors \\
\hline a. Main activities & Collecting milk & Collecting milk & Collecting milk \\
b. Membership & 7,190 members in 2015 & 466 members in 2015 & 200 members in 2015 \\
c. Coordination & $\begin{array}{l}\text { Captive type while the relation- } \\
\text { ship with farmers was based on }\end{array}$ & $\begin{array}{l}\text { Captive type while the relation- } \\
\text { ship with farmers was based on }\end{array}$ & $\begin{array}{l}\text { Captive type while the relation- } \\
\text { ship with farmers was based on } \\
\text { trust. }\end{array}$ \\
& $\begin{array}{l}\text { trust. } \\
\text { Official legal standard required } \\
\text { by the milk processing compa- } \\
\text { nies. Bonus provided. }\end{array}$ & $\begin{array}{l}\text { Milk processor required offi- } \\
\text { cial legal standard. Bonus was } \\
\text { provided. }\end{array}$ & $\begin{array}{l}\text { Official legal standard required } \\
\text { nyies. No bonus provided }\end{array}$ \\
& &
\end{tabular}

Comparison:

- The large cooperative had the highest number of members.

- $\quad$ To meet the requirement, each cooperatives and private collectors had their own standard rules and regulations on milk quality standard.

termined on the quality of milk and paid in cash twice a month. The quality criteria confirmed by Foreman \& de Leeuw (2013) who said that fat, protein and total solids content of the milk are the chemical compositions considered for payment criteria. The farmers' group leaders went to milk collecting actors' offices and received the money on behalf of the members. The group leaders distributed the money to the group members based on the quantity and quality of milk deposited (Table 5).

\section{Financial Management and Services Provided}

The sale of milk was the main source of income for the milk collecting actors. Other sources of income 
Table 4. Milk collection and milk quality of milk collecting actors

\begin{tabular}{|c|c|c|c|}
\hline & Large cooperative & Small cooperative & Private collectors \\
\hline \multicolumn{4}{|l|}{ Milk collection } \\
\hline a. Farmers level & $\begin{array}{l}\text { At the milk collection shed, staff } \\
\text { recorded the total volume of milk } \\
\text { and checked the quality of milk } \\
\text { physically from each farmer. } \\
\text { Randomly checked was done } 4 \\
\text { times in } 2 \text { weeks to check the qual- } \\
\text { ity at the laboratory and set the } \\
\text { price. }\end{array}$ & $\begin{array}{l}\text { There is no milk collection shed. } \\
\text { Staff recorded the amount of milk } \\
\text { and checked the quality of milk } \\
\text { physically. Randomly checked } \\
\text { was done } 4 \text { times in } 2 \text { weeks to } \\
\text { check the quality and set the } \\
\text { price. }\end{array}$ & $\begin{array}{l}\text { The farmers' group leaders col- } \\
\text { lected the milk from their mem- } \\
\text { bers, record the milk quantity of } \\
\text { each farmer and deliver the milk } \\
\text { to the cooling centre. The milk } \\
\text { quality checking was done as and } \\
\text { when required. }\end{array}$ \\
\hline \multirow[t]{3}{*}{$\begin{array}{l}\text { b. Cooling } \\
\text { centres }\end{array}$} & $\begin{array}{l}\text { Milk was transferred from trucks } \\
\text { by pumps, then filtered and stored } \\
\text { in big tanks to be cooled at } 4^{\circ} \mathrm{C} \text {. } \\
\text { Sample of milk was checked in } \\
\text { the laboratory and the result was } \\
\text { reported. Bacterial activity tested. }\end{array}$ & $\begin{array}{l}\text { Milk was transferred from } \\
\text { trucks by pumps, then filtered } \\
\text { and stored in cooling unit to be } \\
\text { cooled at } 4^{\circ} \mathrm{C} \text {. Sample of milk } \\
\text { was checked in the laboratory. } \\
\text { No bacterial activity tested. }\end{array}$ & $\begin{array}{l}\text { Staff of the private company } \\
\text { recorded the milk quantity and } \\
\text { checked the milk quality then } \\
\text { stored the milk into cooling unit. } \\
\text { No bacterial activity tested. }\end{array}$ \\
\hline & \multicolumn{3}{|l|}{ Comparison: } \\
\hline & \multicolumn{3}{|c|}{$\begin{array}{l}\text { The large cooperative had better infrastructure compared to others. Both cooperatives had strict procedures } \\
\text { compared to the private collectors. There was no quality checking at the farmers level for the private collectors. }\end{array}$} \\
\hline \multicolumn{4}{|c|}{${ }{ }^{P}$} \\
\hline a. Total solids & \multicolumn{2}{|l|}{$11.87 \%$} & $11.70 \%$ \\
\hline \multirow[t]{3}{*}{ b. Total bacteria } & 0.88 million $\mathrm{cfu} / \mathrm{mL}$ & 1.4 million $\mathrm{cfu} / \mathrm{mL}$ & 2 million cfu/mL \\
\hline & \multicolumn{3}{|l|}{ Comparison: } \\
\hline & \multicolumn{3}{|c|}{$\begin{array}{l}\text { The large cooperative had better quality because of the bacterial content was less than the others where the } \\
\text { private company still had high number of bacteria content. }\end{array}$} \\
\hline
\end{tabular}

Table 5. Milk price of milk collecting actors

\begin{tabular}{|c|c|c|c|}
\hline Parameters & Large cooperative & Small cooperative & Private collectors \\
\hline \multicolumn{4}{|l|}{ Milk price (IDR) } \\
\hline a. Farmers level & 4,700 & 4,600 & 4,400 \\
\hline \multirow{3}{*}{ b. Farmers' group leader level } & 4,700 & 4,600 & 4,600 \\
\hline & \multicolumn{3}{|l|}{ Comparison: } \\
\hline & \multicolumn{3}{|c|}{$\begin{array}{l}\text { There was a different milk price between farmers and group leader of farmers in the } \\
\text { private company. This was due to the group leaders having to collect milk from each } \\
\text { farmer by their own and transport the milk to the cooling centres. }\end{array}$} \\
\hline
\end{tabular}

included the sale of concentrates, processed milk products, daily groceries and dairy farming. The profit generated by the large cooperative from selling milk was used to cover operational costs like staff salary and maintenance of infrastructure. Other sources of funding were received as loans from financial institutions, grants from national or international organisations, grants from NGOs, government and corporate social responsibility programs of private companies. Some funding and income were also subsidize to provide services (Table 6).

\section{DISCUSSION}

The large cooperative was able to run it function properly in marketing of farmers' milk. Moustier et al. (2010) said that farmer's organizations, in a role of intermediaries, are able to connect the farmers and supermarkets by providing economies of scale and specialized skills in assembling, grading, and transfer- ring information between buyers and sellers. Mangnus \& Piters (2010) also said that producer organizations can play a role in facilitating private sectors and small scale producers in improving their business relation. The large and the small cooperative supplied $80 \%$ and $6 \%$ of the milk respectively, while the remaining milk was supplied by private companies. There was a huge difference in the price of fresh milk at consumers' level between the milk sold by processing companies compared to milk collecting actors (Figure 1). The difference in price is due to the tetra packaging of milk from the processing companies while the milk sold in plastic package are from other milk collecting actors. Tetra packaged milk from milk processing companies were sold in supermarkets, while the plastic packaged milk were sold to the consumers directly on the spot.

The large cooperative had the highest number of members. Coordination between farmers and milk collecting actors was semi-formal where the information 
Table 6. Services provided of milk collecting actors

\begin{tabular}{|c|c|c|c|}
\hline Services & Large cooperative & Small cooperative & Private collectors \\
\hline $\begin{array}{l}\text { a. Livestock } \\
\text { services }\end{array}$ & $\begin{array}{l}\text { The cooperatives provided feed } \\
\text { concentrate on credit basis, } \\
\text { veterinary services, training and } \\
\text { extension }\end{array}$ & $\begin{array}{l}\text { The cooperatives provided feed } \\
\text { concentrate on credit basis, } \\
\text { veterinary services, training and } \\
\text { extension }\end{array}$ & $\begin{array}{l}\text { Only provided veterinary ser- } \\
\text { vices, training and extension }\end{array}$ \\
\hline $\begin{array}{l}\text { b. Financial } \\
\text { services }\end{array}$ & $\begin{array}{l}\text { Provided scholarship for farmers' } \\
\text { children education, loan with } 0 \% \\
\text { interest rate and supported farm- } \\
\text { ers in applying for credit program } \\
\text { with Banks }\end{array}$ & $\begin{array}{l}\text { Provided loan with } 0.4 \% \text { interest } \\
\text { rate and supported farmers in ap- } \\
\text { plying for credit program }\end{array}$ & $\begin{array}{l}\text { Provided loan with } 1.5 \% \text { inter- } \\
\text { est rate }\end{array}$ \\
\hline c. Social services & $\begin{array}{l}\text { Provided groceries store and } \\
\text { farmers health care }\end{array}$ & Provided groceries store & No services offered \\
\hline & \multicolumn{3}{|c|}{$\begin{array}{l}\text { Comparison: } \\
\text { - The private collectors provided loans with the highest interest rate compared to others } \\
\text { - } \quad \text { Both cooperatives provided feed concentrate and credits with low interest rates; they also supported } \\
\text { farmers in accessing credit from bank, and with the groceries store. } \\
\text { - Only the large cooperative provided scholarships for the farmers' children education and health care. }\end{array}$} \\
\hline
\end{tabular}

flow was flexible. KIT \& IIRR (2008) said that coordination is a major element in strengthening chain relation. A lead firm is crucial in coordination and organizing the value chain. However, the relation between the cooperatives and dairy farmers was based on trust and commitment between each other. It was also found that farmers sometimes breached the trust and commitments in a bid to gain short-term profits such as adulteration. Therefore, to solve this problem, a written (and legal) contract seem to be crucial. Contract farming requires close supervision to control and maintain product quality that can benefit the farmers' productivity including quality and quantity (Eaton \& Shepherd, 2001). It can also guarantee both parties to achieve product consistency.

All the milk collecting actors applied usual standards determined by leading milk processing companies. According to M4P (2008), coordination structures, rules and regulations are the dimensions of the value chain governance. Actors will collaborate to set, monitor and facilitate these parameters by certain agreement. To meet requirements, both cooperatives and the private company had their own standard rules and regulations on milk quality. Some interventions to meet the product requirements were initiated by the large cooperative (supplier) along with the milk processing companies (buyers). Nevertheless, the large cooperative still had difficulties to fulfil the increasing standards of milk processors every year because of the inconsistent capability of the dairy farmers to produce good quality of milk. Food trade development, especially demand for agricultural products with high quality standards is increasing with increased food safety standards of market demands (Tallontire et al., 2011). Therefore, private standards increased the requirement for agri food products to assure supply to market.

Despite having met the national standards, the large cooperative could not adequately regulate the milk quality of its members. Decreasing total solids, adulteration, higher plate count and antibiotics were still common. Some farmers were not aware of milk hygienic handling practices. They still used plastic buckets to store the milk. Plastic buckets according to Prihutomo et al. (2015) are the largest contributor of high bacterial contamination in milk. Polypropylene plastic bucket can spread the residue caused by the physical and chemical properties of these materials by food products, especially milk. This observation also found that there was poor sanitation of milking equipment and milking procedures.

Eventhough milk from the large cooperative had less bacterial content compared to other milk collecting actors, the price margin obtained by the large cooperative from the milk processing companies was very small. Similar finding was reported by Wouters (2009), who stated that the competition for the supply of raw milk and raw milk quality was the major problem in Indonesia. The author confirmed that the milk qualitybased payment schemes were introduced, yet the price differences were very small. The large cooperative depended on milk processing companies as the buyers, the processing companies determined the price and fixed product requirements. Nugroho (2012) reported that the domestic milk price depends on the price of milk worldwide. But the price of fresh milk is totally dependent on the interests of milk processing companies. This led to less bargaining power for the suppliers. Understanding the lead firm regulation setting can help micro and small enterprises and other firms to integrate and coordinate their activities to develop their business performance (Trebbin, 2014). It was found that the buyers did not renew the milk price every three months as per the renewal requirement set by the Indonesian government. This led to fixed payments to farmers for a long period of time despite changes in cost of production over time. Due to the asymmetry power where buyers have control over the price and product requirements, the dairy processing industries have not been able to enforce the decision on the milk price. 
All respondents shared the view that the large cooperative was very transparent on financial transactions and accounting, and had full trust in the cooperative's financial management. Trust is required to secure a credible commitment from different parties to cooperate on mutually beneficial actions and investment (Nguyen \& Tran 2014). Though the turnover of the large cooperative was huge, the net income was very low. This is attributed to the repayment of milk to the members. The cooperative only earned a small margin after adding value to the milk. Eventhough the large cooperative tried to diversify the income sources through sale of dairy cow feed and sett up grocery shops, the cost of raw materials was too high for substantial additional income. The net income from the processed milk looks promising. But the large cooperative only processed a small quantity of milk due to limitation on equipment and staff. Zott \& Amit (2010) said that the innovation is a strategic tool that has special characteristic, which is difficult to copy by other competitors that will indicate the sustainability of the business.

Wongtschowski et al. (2013) said that three main types of actors who are involved in the business services are clients, service providers, and financers. All the respondents agreed that the services provided by the large cooperative were adequate. Different social and member welfare services were provided but technical services were hardly provided to the members. Both the large cooperative and the members did not focus on sustainability of the business such as fodder availability : the total number of members remained stagnant or were declining. Providing comprehensive services could help build farmers commitment as stated by Borda-Rodriguez \& Vicari (2014). In order to increase the milk quantity, the large cooperative members should be trained by the cooperative experts on fodder production that will help them to improve forage productivity. The large cooperative could also work in collaboration with the Ministry of Agriculture and other related service providers i.e. universities and NGOs to deliver these trainings (Sembada et al., 2016). Achchuthan \& Kajananthan (2012) mentioned that besides milk marketing, milk collectors also provide services that aim to increase the business of the farmers. It is also supported by Zheng et al. (2011) who said that in order to increase the benefits of the farmers, it needs support from other stakeholders to better link farmers to market in a sustainable way. Therefore, the large cooperative needs to revise the contract with the Ministry of Forestry and negotiate the opportunity to lease more land to its members to solve the fodder shortage. In addition, private land which is left fallow could also be leased to the dairy farmers for fodder production.

\section{CONCLUSION}

Milk collecting actors played an active role in various activities in the milk value chain. The large cooperative had better performance in service provision, it also had better infrastructures in milk collection and milk quality assessment compared to other milk collecting actors. Nevertheless, the large cooperative was not the only milk collecting actors in West Bandung Regency. Hence, other factors must be taken into account in the farmers'choices for one or another outlet. One important determinant is the willingness of the various milk collection actors to support farmers in their business operations and to build trust in the milk transactions.

\section{REFERENCES}

Achchuthan, S. \& R. Kajananthan. 2012. A study on value chain analysis in dairy sector Kilinochchi District, Sri Lanka. Glob. J. Managem. Busin. Res. 12: (Issue 21, version 1.0).

Borda-Rodriguez, A. \& S. Vicari. 2014. Rural co-operative resilience: the case of Malawi. J. Coop. Organiz. Managem. 2: 43-55. https://doi.org/10.1016/j.jcom.2014.03.002

DJPKH (Direktorat Jenderal Peternakan dan Kesehatan Hewan). 2013. Statistik Peternakan dan Kesehatan Hewan. Kementerian Pertanian Republik Indonesia, Jakarta.

Eaton, C. \& A. W. Shepherd. 2001. Contract farming. Partnerships for growth. FAO Agricultural Services Bulletin 145. Rome.

FAO (Food and Agriculture Organisation). 2014. Developing Sustainabile Food Value Chains - Guiding Principles. Rome.

Foreman, I. \& B. de Leeuw. 2013. A Quality Based Milk Payment System. A Guideline for Implementation. SNV, The Netherlands.

KIT \& IIRR. 2008. Trading Up: Building Cooperation Between Farmers and Traders in Africa. Royal Tropical Institute (KIT) and International Institute of Rural Reconstruction (IIRR). KIT publishers, Amsterdam.

Mangnus, E. \& B. D. S. Piters. 2010. Dealing With Small Scale Producers: Linking Buyers and Producers. Royal Tropical Institute (KIT), KIT publishers, Amsterdam.

Morey, P. 2011. Dairy Industry Development in Indonesia: Report for International Finance Corporation (IFC), Final Report - May 2011, Morelink Asia Pacific, 57 p. https:// www.ifc.org/wps/wcm/connect/93f48d00470e3bf883ffd7b2572104ea/Dairy+Industry+Development-2011.pdf?MOD=AJPERES

Moustier, P., P. T. G. Tam, D. T. Anh, V. T. Binh \& N. T. T. Loc. 2010. The role of farmer organizations in supplying supermarkets with quality food in Vietnam. Food Policy 35: 69-78. https://doi.org/10.1016/j.foodpol.2009.08.003

M4P. 2008. Making Value Chains Work Better for the Poor: A Toolbook for Practitioners of Value Chain Analysis. Version 3. UK Department for International Development (DFID). Agricultural Development International. Phnom Penh. Cambodja.

Nguyen V.K. \& V. D. Tran. 2014. The dairy industry in Vietnam: A value chain approach. Int. J. Managing Value Supply Chains 5: 1-16. https://doi.org/10.5121/ijmvsc.2014.5301

Nugroho, B. A. 2012. The relevance of a rules-based fresh milk price structure policy in East Java : an evidence-based assessment. Intern. J. Rural Stud. 19: 1-7 (Article 3).

Prihutomo, S., B. E. Setiani \& D. W. Harjanti. 2015. Screening sumber cemaran bakteri pada kegiatan pemerahan susu di peternakan sapi perah rakyat Kabupaten Semarang. Jurnal Ilmu-Ilmu Peternakan 25: 66-71. https://doi.org/10.21776/ ub.jiip.2015.025.01.10

Priyanti A. \& T. D. Soedjana. 2015. Indonesian dairy industry perspective within the ASEAN economic community. WARTAZOA 25: 159-170. https://doi.org/10.14334/wartazoa.v25i4.1226

Sembada, P., G. Duteurtre, B. P. Purwanto, \& Suryahadi. 2016. Improvement of milk production performances of smallholder farms in West Java (Indonesia). Tropical Animal Health and Production 48:793-799. https://doi.org/10.1007/ s11250-016-1029-2 
Tallontire, A., M. Opondo, V. Nelson, \& A. Martin. 2011. Beyond the vertical? Using value chain and governance as a framework to analyse private standards initiatives in agri-food chains. Agric Hum Values 28: 427-441. https:// doi.org/10.1007/s10460-009-9237-2

Trebbin, A. 2014. Linking small farmers to modern retail through producer organizations - Experiences with producer companies in India. Food Policy 45: 35-44. https:// doi.org/10.1016/j.foodpol.2013.12.007

Wongtschowski, M., J. Belt, W. Heemskerk \& D. Kahan. 2013. The Business of Agricultural Business Services: Working with Smallholders in Africa. Royal Tropical Institute, FAO, and Agri-ProFocus. Amsterdam, Rome and Arnhem.
Wouters, A.P. 2009. Dairy Sector Development Indonesia: Options for Cooperation with The Netherlands. Animal Sciences Group, Wageningen University and Research, The Netherlands.

Zheng, S., Z. Wang, \& S. Song. 2011. Farmers' behaviors and performance in cooperatives in Jilin Province of China: A case study. Elsevier Journal. The Social Science Journal 48: 449-457. https://doi.org/10.1016/j.soscij.2011.05.003

Zott, C. \& R. Amit. 2010. Business model design: An activity system perspective. Long Range Planning 43: 216-226. https://doi.org/10.1016/j.lrp.2009.07.004 